Ekspansi: Jurnal Ekonomi, Keuangan, Perbankan dan Akuntansi

ISSN (Online): 2580-7668 ISSN (Print): 2085-5230

Vol. 12, No. 2 (November 2020), Hal. 209 - 223

\title{
EFEKTIVITAS PENYALURAN PEMBIAYAAN KPR SYARIAH BERSUBSIDI PADA PT BANK BTN SYARIAH CIREBON
}

\author{
Putri Pithaloka Kennedy ${ }^{1}$, Juliana Juliana ${ }^{2}$, Suci Aprilliani Utami ${ }^{3}$ \\ 1,2,3 Ilmu Ekonomi dan Keuangan Islam, Universitas Pendidikan Indonesia, Bandung, \\ Indonesia \\ Email Korespondensi: putripithaloka@student.upi.edu
}

\begin{abstract}
The purpose of this study is to determine the pattern of the procedure for distribution of subsidized Sharia KPR financing at PT. Bank BTN Syariah Cirebon and to find out the level of effectiveness in disbursing subsidized Sharia KPR financing to PT. Bank BTN Syariah Cirebon. The population in this study were subsidized KPR financing customers at PT. Bank BTN Syariah Cirebon. Data collection in this study used Google Form which was distributed to 96 respondents from Cirebon district. The sampling technique used was non-probability-purpose sampling of 96 respondents who had been determined using the Slovin formula. The research method used in this research is descriptive method with a quantitative approach. The data analysis technique used was SPSS 22. Measuring the level of effectiveness of financing using a measure of the effectiveness of all indicators. The results of the effectiveness of subsidized Sharia KPR financing are on the variable effectiveness of indicators of use $85.3 \%$, target accuracy of $84.8 \%$, scope of $85.0 \%$, cost effectiveness of $85.9 \%$, and timeliness of $81.3 \%$. It can be concluded overall that the effectiveness of Subsidized Sharia KPR financing at PT. Bank BTN Syariah Cirebon is very effective with a yield of $84.5 \%$.
\end{abstract}

Keywords: Effectiveness, Subsidized Syariah KPR, BTN Syariah

\begin{abstract}
Abstrak: Tujuan penelitian ini untuk mengetahui pola prosedur penyaluran pembiayaan KPR Syariah bersubsidi pada PT. Bank BTN Syariah Cirebon dan mengetahui tingkat efektivitas penyaluran pembiayaan KPR Syariah bersubsidi pada PT. Bank BTN Syariah Cirebon. Populasi dalam penelitian ini merupakan nasabah pembiayaan KPR Syariah bersubsidi pada PT. Bank BTN Syariah Cirebon. Pengumpulan data dalam penelitian ini menggunakan Google Form yang disebar ke 96 responden dari kabupaten Cirebon. Teknik pengambilan sampel yang digunakan adalah non probability-purpose sampling sebanyak 96 responden yang telah ditentukan mengggunakan rumus slovin. Metode penelitian yang digunakan dalam penelitian ini adalah metode deskriptif dengan pendekatan kuantitatif. Teknik analisis data yang digunakan adalah SPSS 22. Mengukur tingkat efektivitas pembiayaan menggunakan ukuran efektivitas seluruh indikator. Adapun hasil efektivitas pembiayaan KPR Syariah bersubsidi adalah pada variabel efektivitas indikator kegunaan 85,3\%, ketepatan sasaran 84,8\%, ruang lingkup 85,0\%, efektivitas biaya 85,9\%, dan ketepatan waktu 81,3\%. Dapat disimpulkan secara keseluruhan bahwa efektivitas pembiayaan KPR Syariah Bersubsidi pada PT. Bank BTN Syariah Cirebon adalah sangat efektif dengan hasil sebesar $84,5 \%$.
\end{abstract}

Kata Kunci: Efektivitas, KPR Syariah Bersubsidi, BTN Syariah

DOI: $10.35313 /$ ekspansi.v12i2.2224 


\section{PENDAHULUAN}

Bank di Indonesia tentunya banyak memiliki program rumah untuk masyarakat, yang menawarkan produk rumah dengan menawarkan KPR bersubsidi. BTN Syariah sebagai bank yang berkonsentrasi dalam menawarkan kredit rumah bersubsidi maupun tidak bersubsidi serta menjadi solusi dari permintaan rumah yang meringankan dan sesuai syariah, hal ini akan membuat masyarakat mudah untuk mendapatkan kredit rumah dengan berbagai prosedur sebagai tahapan dalam memiliki rumah sesuai dengan kebutuhan dan kemampuannya.

BTN menjadi pemimpin pasar pembiayaan perumahan di Indonesia dengan penguasaan pangsa pasar total KPR sebesar 35,23\%. Peran bank BTN sangat dominan dengan menguasai pangsa pasar lebih dari 98\% dari total penyaluran FLPP tahun 2017, 2018 dan 2019. Total KPR yang sudah disalurkan bank BTN sejak 1976 sampai dengan 2019 berjumlah sekitar Rp 150 triliun yang telah dimanfaatkan oleh lebih dari 3,5 juta masyarakat Indonesia (BTN, 2019).

Pertumbuhan ekonomi bukan hanya melibatkan unsur ekonomi secara makro akan tetapi secara mikro harus diperhatikan, seperti halnya kebutuhan akan KPR Syariah bersubsidi yang didalamnya terdapat ketentuan-ketentuan yang mengatur akan pertumbuhan ekonomi. Secara Islam bukan tingginya barang dan jasa tetapi dari semua aspek pemenuhan primer harus terpenuhi (Juliana, Marliana, Saadillah, \& Maryam, 2018).

Berdasarkan hasil wawancara dari ketua REI (Real Estate Indonesia) se-Wilayah 3 Cirebon, Gunadi (26 Maret 2020) menyatakan bahwa (1) kebutuhan rumah bersubsidi se-Wilayah 3 Cirebon rata-rata mencapai 13 ribu unit dengan pencapaian rata-rata pertahun sebesar 7-8 ribu unit, (2) persentase kebutuhan rumah di Kota Cirebon sebesar 20\%, (3) persentase kebutuhan rumah di Kabupaten Cirebon sebesar 45\%, (4) persentase kebutuhan rumah di Majalengka sebesar 5\%, (5) persentase kebutuhan rumah di Kuningan sebesar $15 \%$ dan (6) persentase kebutuhan rumah di Indramayu sebesar 15\%, maka dari hasil wawancara diatas dapat disimpulkan bahwa kebutuhan rumah di Kabupaten Cirebon sangat tinggi. Banyak masyarakat khususnya masyarakat berpenghasilan rendah (MBR) yang belum memiliki rumah dikarenakan selain tingginya harga lahan, sulitnya perijinan bangunan, juga menyangkut pada permasalahan sistem pembiayaan perumahan terhadap kemampuan masyarakat berpenghasilan rendah (Arum Novia W, Astuti W, \& Galeng Y, 2011).

KPR Subsidi adalah suatu kredit yang diperuntukkan pada masyarakat berpenghasilan rendah (MBR) yang disubsidikan khusus oleh pemerintah yang bekerjasama dengan Kementerian Pekerjaan Umum dan Perumahan Rakyat (PUPR) dalam rangka memenuhi kebutuhan perumahan. Berdasarkan peraturan menteri yaitu Peraturan Menteri Pekerjaan Umum (PU) Rakyat Republik Indonesia Nomor 21 / PRT / M / 2016 tentang Perumahan dan Kawasan Permukiman, masyarakat yang berpenghasilan rendah mendapatkan dukungan kepemilikan atas rumah melalui kebijakan kemudahan, bantuan pembangunan dan perolehan rumah.

Kelompok sasarannya adalah keluarga atau perorangan baik yang berpenghasilan tetap maupun tidak tetap,tidak memiliki rumah yang dibuktikan dengan surat 
pernyataan dari yang bersangkutan dan diketahui oleh kepala desa/lurah setempat, belum pernah menerima subsidi KPR dari pemerintah, memiliki Nomor Pokok Wajib Pajak (NPWP) dan termasuk kelompok masyarakat berpenghasilan rendah yang berpenghasilan perbulan maksimal sebesar Rp. 4.000 .000 (BTN, 2017). Bank Syariah mampu mewujudkan secara nyata suatu sistem yang sangat kompleks yaitu mampu berkompetitif, efisien, serta memenuhi prinsip kehatian melalui kegiatan pembiayaan berbasis bagi hasil dan transaksi rill dalam kerangka berkeadilan menuju kebaikandalam mencapai kemaslahatan masyarakat (Juliana \& Marliana, 2016).

KPRS bersubsidi mempunyai suatu masalah yaitu pertama, timbulnya penunggakan penyaluran pembayaran angsuran yang dapat menyebabkan kredit macet. Hal ini disebabkan oleh faktor internal dan faktor eksternal, faktor internal yaitu pihak bank, sedangkan faktor eksternal yaitu pihak debitur. Faktor internal biasanya terjadi karena kelalaian dari pihak bank, sedangkan faktor eksternal terjadi karena kesengajaan yang dilakukan pihak debitur atau biasanya saat sudah melakukan kredit pihak debitur mengalami kondisi penurunan keuangan sehingga yang awalnya mampu untuk menyetor tagihan sekarang tidak mampu lagi. Ketidakmampuan dalam angsuran terkendala berkaitan dengan faktor pekerjaan maupun lainnya. (Takalamingan, Saerang, \& Kalalo, 2018).

Kedua, unit KPRS bersubsidi sebanyak 5.108 di Bank BTN Syariah belum dimanfaatkan oleh debitur atau pemilik asli. Rumah-rumah tersebut tidak dihuni, dialihkan atau proses dialihkan kepada pihak lain dan masih belum tersalurkan kepada masyarakat berpenghasilan rendah secara merata, sehingga masih belum efektifnya program KPR bersubsidi dari pemerintah. Ketiga, Masyarakat berpenghasilan rendah dihadapkan pada terbatasnya akses mereka untuk menjangkau fasilitas KPR yang disediakan perbankan. Keterbatasan tersebut menyebabkan penyediaan KPRS bersubsidi terkadang kurang tepat sasaran, yaitu jatuh pada kelompok masyarakat berpenghasilan menengah atau tinggi.

\subsection{Rumusan Masalah Penelitian}

a) Bagaimana pola penyaluran pembiayaan KPR Syariah bersubsidi PT. Bank BTN Syariah Cirebon?

b) Bagaimana tingkat efektivitas pembiayaan KPR Syariah bersubsidi PT. Bank BTN Syariah Cirebon?

\subsection{Tujuan penelitian}

Tujuan dari penelitian ini berdasarkan pertanyaan penelitian yang telah dipaparkan yaitu untuk mengetahui pola prosedur penyaluran pembiayaan KPR Syariah Bersubsidi pada PT. Bank BTN Syariah Cirebon dan mengetahui tingkat efektivitas penyaluran pembiayaan KPR Syariah Bersubsidi pada PT. Bank BTN Syariah Cirebon. 


\section{TINJAUAN PUSTAKA}

\subsection{Efektifitas}

Efektivitas mempunyai kata dasar "efektif", menurut Kamus Besar Bahasa Indonesia, efektif memiliki arti "ada efeknya seperti akibatnya, pengaruhnya, kesannya. Efektivitas dapat memberikan hasil atau berhasil guna tentang usaha atau tindakan" (KBBI, 2018). Efektivitas pembiayaan di Bank Pakistan ternyata belum dapat memenuhi target dan sasaran program. Karena masih terdapat perbankan yang belum menunjang efektivitas pembiayaannya (Abbas, Azid, \& Azrin $\mathrm{Hj}$, 2016).

Siskawati mengemukakan bahwa "Efektivitas pembiayaan dapat dinyatakan sebagai tingkat keberhasilan dalam usaha untuk mencapai tujuan atau sasaran" (Sholihat, 2015). Peneliti berkesimpulan bahwa efektivitas menunjukkan keberhasilan dari segi tercapai tidaknya suatu sasaran yang telah ditetapkan. Jika hasil kegiatan mendekati sasaran, maka akan semakin tinggi efektivitasnya. Kriteria yang dapat digunakan untuk menilai efektivitas pembiayaan, yaitu mencakup kegunaan, ketepatan sasaran, ruang lingkup, efektivitas pembiayaan, dan ketepatan waktu.

Indikator efektivitas pembiayaan dalam KPR syariah bersubsidi meliputi beberapa hal yaitu:

1) Kegunaan

Indikator kegunaan dipakai sebagai bagian dasar dalam penentuan efektif tidaknya pelaksanaan sistem pembiayaan yang selalu dibicarakan oleh pihak bank. Kegunaan tersebut ditujukan agar masyarakat mudah menjangkau KPR Subsidi baik dari segi penghasilan dan kemudahan prosedur pengajuan pembiayaan KPR syariah bersubsidi sebagai bagian dari suatu sistem pembiayaan yang benar dan tepat, sehingga para nasabah akan mudah memahaminya. Kemudahan akan bisa tercapai manakala kita mampu menerapkan dari pola indikator yang sudah ditentukan secara benar dan tepat dalam penyelesaian sehingga kegunaan dalam pelaksanaan pembiayaan akan berdampak positif terhadap pembiayaan yang muncul di prosedur KPR syariah bersubsidi secara maksimal. (Sukanto \& T. Hani Handoko, 2012).

2) Ketepatan Sasaran

Program KPR syariah bersubsidi bagi masyarakat yang akan mengambil harus tepat sasaran dalam kepemilikan rumah bila tidak tepat sasaran maka apa yang menjadi tujuan utama akan sangat menyimpang. Kemudahan yang disampaikan pihak bank dalam pengambilan rumah bersubsidi harus sampai pada masyarakat sebagai nasabah sehingga masyarakat akan merasa nyaman akan informasi yang di dapat secara tepat. Masyarakat berpenghasilan rendahpun akan dimudahkan dalam pemberian suatu prosedur pengambilan rumah bersubsidi melalui proses yang sesuai dari Bank BTN Syariah (Sukanto \& T. Hani Handoko, 2012).

3) Ruang Lingkup

Ruang lingkup KPR syariah bersubsidi meliputi kemudahan dalam persyaratan pengajuan. Masyarakat berpenghasilan rendah akan turut memperhatikan beberapa prosedur dalam pengambilan rumah bersubsidi sehingga termudahkan dan yang paling utama adalah nasabah akan berpeluang bila dalam pekerjaannya ada kemapanan 
sehingga masyarakat yang akan mengambil KPR Subsidi harus memenuhi persyaratan yang tentunya sudah diverifikasi secara kooperatif yang tertuang dalam peraturan kementerian perumahan rakyat Nomor 10/PRT/M/2019 Pasal 54 ayat (5) (Ravianto J, 2014).

4) Efektivitas Biaya

Efektivitas biaya dalam KPR syariah bersubsidi selayaknya akan diperuntukan kepada masyarakat berpenghasilan rendah tetapi ada beberapa hal yang menjadi syaratnya seperti slip gaji penghasilan minimal, KTP, kartu keluarga, tabungan, sehingga persyaratan akan administrasi menjadi efektif terhadap biaya administrasi yang dikenakan nasabah sesuai kemampuan nasabah, biaya tidak tiba-tiba akan muncul di nasabah akan tetapi ada penetapan besaran margin pada Bank BTN Syariah yaitu $5 \%$ sesuai dengan peraturan kementerian perumahan rakyat Nomor 10/PRT/M/2019 Pasal 54 ayat (5) (BTN, 2019), sehingga nasabah akan menjadi mengerti akan penetapan biaya-biaya yang muncul saat akad kredit.

5) Ketepatan Waktu

Dokumen yang lengkap dan tepat waktu akan semakin jelas bila diproses untuk pencairan dana atau KPR syariah bersubsidi secara cepat tanpa ada kendala bila nasabah memperhatikan akan prosedur dan persyaratan secara baik maka ketepatan waktu pencairan pembiayaan KPR syariah bersubsidi membutuhkan waktu dalam proses pembiayaannya. KPR syariah bersubsidi perlu waktu yaitu proses waktu yang tidak lama yaitu 1- 2 hari kerja setelah dokumen permintaan pencairan biaya disampaikan. Untuk pembayaran angsuran nasabah diberikan keringanan sesuai dengan aturan yang berlaku pada bank sehingga untuk membayar perlu waktu dalam jangka 15 tahun - 20 tahun (Makmur, 2011).

Berdasarkan indikator-indikator diatas bahwa yang akan diteliti dalam penelitian ini adalah 5 indikator efektivitas yaitu indikator kegunaan, ketepatan sasaran, ruang lingkup, efektivitas biaya, dan ketepatan waktu, dari kelima indikator tersebut akan menjadi suatu acuan yang jelas dan konkret. Penelitian efektivitas pembiayaan KPR syariah bersubsidi dinilai berdasarkan pendapat responden mengenai kemudahan mekanisme proses pembiayaan KPR untuk penyediaan KPR syariah bersubsidi, hal ini tentunya akan berdampak pada hasil penelitian lebih lanjut.

\subsection{Pembiayaan}

Menurut UU No. 7 Tahun 1992 tentang perbankan sebagaimana telah diubah menjadi UU No. 10 Tahun 1998 tentang Perbankan dalam pasal 1 nomor 12: "Pembiayaan berdasarkan prinsip syariah adalah penyediaan uang atau tagihan berdasarkan persetujuan atau kesepakatan antara bank dengan pihak lain bisa masyarakat umum maupun pada nasabah yang akan diberikan suatu pembiayaan yang mewajibkan pihak yang dibiayai dapat mengembalikan uang atau tagihan tersebut setelah jangka waktu tertentu dengan imbalan atau bagi hasil hal ini berdasar pada suatu kesepakatan dan pola pembiayaannya jelas, transparan dan tepat dalam jangka waktu yang telah ditentukan bila tidak ada kejelasan maka proses ini akan menjadi 
kurang pas jadi proses pembiayaan akan menjadi baik manakala prosesnya jelas" (Choiriyah, 2019).

Perbankan dalam pasal 1 Nomor 13: "prinsip syariah adalah aturan perjanjian berdasarkan hukum islam antara bank dengan pihak lain untuk penyimpanan dana dan atau pembiayaan kegiatan usaha yang dinyatakan dengan syariah, seperti: pembiayaan berdasarkan prinsip bagi hasil (mudharabah), pembiayaan berdasarkan prinsip penyertaaan modal (musyarakah), prinsip jual beli barang dengan memperoleh keuntungan (murabahah) atau pembiayaan barang modal berdasarkan prinsip sewa murni tanpa pilihan (ijarah), atau dengan adanya pilihan pemindahan kepemilikan barang yang disewa dari pihak bank oleh pihak lain" (Choiriyah, 2019). Prinsip berbisnis adalah pertama customer oriented yang selalu menjaga kepuasan pelanggan, kedua transparansi yaitu mengenai mutu, kuantitas, komposisi agar menimbulkan rasa aman dan nyaman bagi konsumen (Juliana, Faathir, \& Sulthan, 2019).

\subsection{KPR Syariah bersubsidi}

Pembiayaan KPR Syariah bersubsidi pada bank BTN Syariah Cirebon umumnya menggunakan akad murabahah. Murabahah adalah transaksi jual beli suatu barang sebesar harga barang ditambah dengan margin yang disepakati antara kedua belah pihak, dimana penjual menjelaskan terlebih dahulu harga perolehan kepada pembeli (Muhammad, 2015). Salah satu produk pembiayaan yang menggunakan akad murabahah yaitu produk kredit pemilikan rumah (KPR). Pembiayaan pemilikan rumah kepada perorangan untuk memenuhi seluruh kebutuhan rumah dengan menggunakan prinsip jual beli (murabahah). Pembayaran yang dilakukan secara angsuran dengan jumlah angsuran yang sudah ditetapkan di awal dan dibayar setiap bulan (Gd Permadi, 2018).

\section{METODE PENELITIAN}

Dalam penelitian ini peneliti menggunakan metode deskriptif dengan pendekatan kuantitatif. Metode deskriptif dalam penelitian ini akan menggambarkan atau mendeskripsikan permasalahan efektivitas penyaluran pembiayaan KPR Syariah bersubsidi pada Bank BTN Syariah Cirebon. Metode kuantitatif merupakan suatu proses menemukan pengetahuan yang menggunakan data berupa angka sebagai alat menganalisis keterangan mengenai apa yang ingin diketahui (Ferdinand A. , 2014).

Desain penelitian yang digunakan dalam penelitian ini menggunakan desain penelitian deskriptif. Desain deskriptif ditujukan untuk menjawab atas pertanyaanpertanyaan tentang siapa, apa, kapan, di mana dan bagaimana keterkaitan dengan penelitian tertentu. Penelitian deskriptif digunakan untuk memperoleh informasi mengenai status fenomena variabel atau kondisi situasi (Notoatmodjo, 2012).

Dalam penelitian ini, populasi yang dituju yaitu nasabah pembiayaan KPR syariah bersubsidi pada PT. Bank BTN Syariah Cirebon, agar mempermudah penelitian penulis mengambil sampel dari nasabah perumahan KPR bersubsidi. Pada penelitian ini peneliti mengambil lima perumahan bersubsidi yang memiliki nasabah banyak di Kabupaten Cirebon, yaitu Bukit Ciperna, Graha Bukit Ciperna, Bumi Asri Dawuan, 
Graha Beber Raya, Graha Cendana Pabuaran. Jumlah populasi dalam penelitan ini yaitu sekitar 103 nasabah KPR Bersubsidi dalam kurun waktu 2016-2019, maka sampel diambil sejumlah 96 responden dari kabupaten Cirebon yang tersebar dalam 5 perumahan bersubsidi.

Perhitungan sampel yang dihasilkan adalah 95,8 dan dibulatkan menjadi 96 responden. Pada proses pemilihan responden digunakan stratified random sampling. Stratified random sampling adalah teknik yang digunakan bila populasi mempunyai anggota atau unsur yang tidak homogen dan berstrata secara proposional. Sampel ini diambil dari nasabah pembiayaan KPR bersubsidi pada bank BTN Syariah Cirebon.

Teknik pengumpulan data menggunakan angket yang disebar melalui google form dan wawancara pada Bank BTN Syariah Cirebon. Teknik analisis data menggunakan SPSS 22 dalam menguji validitas, reliabilitas, dan ukuran efektivitas.

\section{HASIL DAN PEMBAHASAN}

Hasil penelitian lapangan berupa data-data yang berkaitan dengan rumusan masalah, tujuan penelitian, serta hasil pengolahan dan analisis data untuk kemudian dapat dideskripsikan dengan penafsiran dan pemaknaan terhadap semua data hasil penelitian yang ada. Hasil penelitiannya yaitu karakteristik umum responden, hasil uji validitas, hasil uji reliabilitas, dan hasil efektivitas. Namun sebelum memaparkan hasil pengujian secara statistik, akan dipaparkan terlebih dahulu mengenai analisis deskriptif nasabah pembiayaan KPR syariah bersubsidi pada PT. Bank BTN Syariah Cirebon yang menjadi responden penelitian yaitu sebanyak 96 responden.

Secara keseluruhan, karakteristik responden berdasarkan jenis kelamin dapat dilihat pada tabel 4.1 berikut:

Tabel 4. 1

Karakteristik Responden berdasarkan Jenis Kelamin

\begin{tabular}{|c|c|c|c|c|c|}
\hline \multicolumn{6}{|c|}{ Jenis Kelamin } \\
\hline & & Frequency & Percent & Valid Percent & $\begin{array}{c}\text { Cumulative } \\
\text { Percent }\end{array}$ \\
\hline \multirow[t]{3}{*}{ Valid } & Laki-laki & 49 & 51.0 & 51.0 & 51.0 \\
\hline & Perempuan & 47 & 49.0 & 49.0 & 100.0 \\
\hline & Total & 96 & 100.0 & 100.0 & \\
\hline
\end{tabular}

Dapat dilihat pada Tabel 4.1 bahwa berdasarkan jenis kelamin, responden Lakilaki yang mendominasi pembiayaan KPR syariah bersubsidi yaitu sebanyak 49 orang nasabah atau sebesar 51\% sedangkan responden Perempuan sebanyak 47 orang nasabah atau sebesar 49\%. Banyaknya nasabah dengan Jenis Kelamin Laki-laki telah mendominasi jumlah nasabah yang mengajukan pembiayaan KPR syariah bersubsidi pada PT. Bank BTN Syariah Cirebon.

Karakteristik Responden Berdasarkan Usia

Secara keseluruhan, karakteristik responden berdasarkan Usia dapat dilihat pada Tabel 4.2 berikut: 
Tabel 4. 1

\begin{tabular}{|c|c|c|c|c|c|}
\hline \multicolumn{6}{|c|}{ Karakteristik Responden berdasarkan Usia } \\
\hline & & Frequency & Percont & Valid Percent & $\begin{array}{l}\text { Cumbiative } \\
\text { Percent }\end{array}$ \\
\hline \multirow[t]{5}{*}{ Valid } & 20 Tahun s.d 30 Tahun & 16 & 16.7 & 16.7 & 16.7 \\
\hline & 31 Tahun s.d 40 Tahun & 29 & 30.2 & 30.2 & 46. \\
\hline & 41 Tatun s.d 50 Tahun & 35 & 36.5 & 36.5 & 83. \\
\hline & 51 Tatun as 60 Tahun & 16 & 16.7 & 16.7 & 100. \\
\hline & Total & 06 & 100.0 & 100.0 & \\
\hline
\end{tabular}

Pada Tabel 4.2 responden berdasarkan usia didominasi pada usia 41-50 tahun sebanyak 35 orang atau 36,5\%, dilanjutkan nasabah dengan usia 31-40 tahun sebanyak 29 orang atau 30,2\%, nasabah dengan usia 20-30 tahun sebanyak 16 orang atau 16,7\%, dan yang terakhir nasabah dengan usia 51-60 tahun sebanyak 16 orang atau 16,7\%. Banyaknya nasabah dengan usia 41-50 tahun telah mendominasi jumlah nasabah yang mengajukan pembiayaan KPR syariah bersubsidi pada PT. Bank BTN Syariah Cirebon

Karakteristik Responden Berdasarkan Tingkat Pendidikan

Secara keseluruhan, karakteristik responden berdasarkan Tingkat Pendidikan dapat dilihat pada Tabel 4.3 berikut:

Tabel 4. 2

Karakteristik Responden berdasarkan Tingkat Pendidikan

\begin{tabular}{|ll|r|r|r|r|}
\hline & Pendidikan Terakhir \\
\hline & & Frequency & Percent & Valid Percent & $\begin{array}{c}\text { Cumulative } \\
\text { Percent }\end{array}$ \\
\hline Valid & D3 & 10 & 10.4 & 10.4 & 10.4 \\
& S1 & 55 & 57.3 & 57.3 & 67.7 \\
S2 & 12 & 12.5 & 12.5 & 80.2 \\
S3 & 1 & 1.0 & 1.0 & 81.3 \\
SMAVSederajat & 18 & 18.8 & 18.8 & 100.0 \\
& Total & 96 & 100.0 & 100.0 & \\
\hline
\end{tabular}

Pada Tabel 4.3 responden berdasarkan Tingkat Pendidikan didominasi oleh tingkat S1 yaitu sebanyak 55 orang atau sebesar 57,3\%, kemudian pada tingkat Pendidikan SMA yaitu sebanyak 18 orang atau sebesar 18,8\%, tingkat S2 yaitu sebanyak 12 orang atau sebesar $12,5 \%$, tingkat D3 yaitu sebanyak 10 orang atau sebesar 10,4\%, dan yang terakhir pada tingkat S3 sebanyak 1 orang atau sebesar $1 \%$. Banyaknya nasabah dengan Tingkat Pendikan S1 telah mendominasi jumlah nasabah yang mengajukan pembiayaan KPR syariah bersubsidi pada PT. Bank BTN Syariah Cirebon.

Karakteristik Responden Berdasarkan Pekerjaan

Secara keseluruhan, karakteristik responden berdasarkan pekerjaan dapat dilihat pada Tabel 4.4 berikut: 
Tabel 4.3

Karakteristik Responden Berdasarkan Pekerjaan

Pekeriaan

\begin{tabular}{|c|c|c|c|c|c|}
\hline & & Frequency & Percent & Valid Percent & $\begin{array}{c}\text { Cumulative } \\
\text { Percent }\end{array}$ \\
\hline \multirow[t]{17}{*}{ Valid } & bumn & 1 & 1.0 & 1.0 & 1.0 \\
\hline & Buruh & 3 & 3.1 & 3.1 & 4.2 \\
\hline & Dosen & 2 & 2.1 & 2.1 & 6.3 \\
\hline & Guru Honorer & 13 & 13.5 & 13.5 & 19.8 \\
\hline & Honorer staff tu & 1 & 1.0 & 1.0 & 20.8 \\
\hline & Ibu rumah tangga & 3 & 3.1 & 3.1 & 24.0 \\
\hline & Irt & 1 & 1.0 & 1.0 & 25.0 \\
\hline & IRT & 1 & 1.0 & 1.0 & 26.0 \\
\hline & Mengurus Rumah Tangga & 1 & 1.0 & 1.0 & 27.1 \\
\hline & Pegawai Swasta & 16 & 16.7 & 16.7 & 43.8 \\
\hline & Pelatih renang & 1 & 1.0 & 1.0 & 44.8 \\
\hline & Pembina olahraga & 1 & 1.0 & 1.0 & 45.8 \\
\hline & Pengajar barongsai & 2 & 2.1 & 2.1 & 47.9 \\
\hline & Personal trainer fitnes/atlet & 1 & 1.0 & 1.0 & 49.0 \\
\hline & PNS & 33 & 34.4 & 34.4 & 83.3 \\
\hline & Wiraswasta & 16 & 16.7 & 16.7 & 100.0 \\
\hline & Total & 96 & 100.0 & 100.0 & \\
\hline
\end{tabular}

Pada Tabel 4.4 responden berdasarkan pekerjaan didominasi oleh nasabah PNS sebanyak 33 orang atau sebesar 34,4\%, kemudian oleh Wiraswasta sebanyak 16 orang atau sebesar 16,7\% , Pegawai Swasta sebanyak 16 orang atau sebesar 16,7\%, Guru Honorer sebanyak 13 orang atau sebesar 13,5\%, Buruh sebanyak 3 orang atau sebesar $3,1 \%$, Ibu Rumah Tangga sebanyak 6 orang atau sebesar $6,1 \%$, Dosen sebanyak 2 orang atau sebesar 2,1\%, Pengajar Barongsai sebanyak 2 orang atau sebesar 2,1\%, BUMN sebanyak 1 orang atau sebesar 1\%, Honorer Staff TU sebanyak 1 orang atau sebesar $1 \%$, Pelatih Renang sebanyak 1 orang atau sebesar 1\%, Pembina Olah Raga sebanyak 1 orang atau sebesar 1\%, dan yang terakhir Personal Trainer Fitness sebanyak 1 orang atau sebesar $1 \%$. Banyaknya nasabah dengan Tingkat Pekerjaan PNS telah mendominasi jumlah nasabah yang mengajukan pembiayaan KPR syariah bersubsidi pada PT. Bank BTN Syariah Cirebon.

Karakteristik Responden Berdasarkan Tingkat Pendapatan

Secara keseluruhan, karakteristik responden berdasarkan pendapatan dapat dilihat pada Tabel 4.5 berikut: 
Tabel 4. 4

Karakteristik Responden Berdasarkan Tingkat Pendapatan

Tingkat pendapatan rata-rata perbulan

\begin{tabular}{|c|c|c|c|c|c|}
\hline & & Frequency & Percent & Valid Percent & $\begin{array}{l}\text { Cumulative } \\
\text { Percent }\end{array}$ \\
\hline \multirow[t]{6}{*}{ Valid } & $<$ Rp. 1.000 .000 & 12 & 12.5 & 12.5 & 12.5 \\
\hline & $>$ Rp.4.100.000 & 36 & 37.5 & 37.5 & 50.0 \\
\hline & $\begin{array}{l}\text { Rp. } 1.100 .000 \text { - Rp. } \\
2.000 .000\end{array}$ & 10 & 10.4 & 10.4 & 60.4 \\
\hline & $\begin{array}{l}\text { Rp. } 2.100 .000 \text { - Rp. } \\
3.000 .000\end{array}$ & 13 & 13.5 & 13.5 & 74.0 \\
\hline & $\begin{array}{l}\text { Rp. } 3.100 .000 \text { - Rp. } \\
4.000 .000\end{array}$ & 25 & 26.0 & 26.0 & 100.0 \\
\hline & Total & 96 & 100.0 & 100.0 & \\
\hline
\end{tabular}

Pada Tabel 4.5 karakteristik responden berdasarkan pendapatan perbulan didominasi pada pendapatan > Rp 4.100 .000 sebanyak 36 orang atau sebesar 37,5\%, kemudian pendapatan $\mathrm{Rp} 3.100 .000-\mathrm{Rp} 4.000 .000$ sebanyak 25 orang atau sebesar $26 \%$, pendapatan $\operatorname{Rp} 2.100 .000-R p 3.000 .000$ sebanyak 13 orang atau sebesar 13,5\%, pendapatan $<\mathrm{Rp} 1.000 .000$ sebanyak 12 orang atau sebesar $12,5 \%$, dan yang terakhir dengan pendapatan $\mathrm{Rp} 1.100 .000-\mathrm{Rp} 2.000 .000$ sebanyak 10 orang atau sebesar 10,4\%. Nasabah dengan pendapatan > Rp 4.100 .000 sebanyak 36 orang itu menandakan bahwa pembiayaan KPR syariah bersubsidi yang dilakukan atas kerjasama dan peraturan terbaru KEMENPERA dengan Bank BTN Syariah Cirebon tepat sasaran karena batas pendapatan perbulan yaitu Rp. 8.000.000 (Pusat Pengelolaan Dana Pembiayaan Perumahan, 2020).

Berdasarkan hasil penelitian "Efektivitas pembiayaan KPR Syariah Bersubsidi pada PT. Bank BTN Syariah Cirebon” diperoleh hasil sebagai berikut :

1) Kegunaan

Indikator kegunaan dipakai sebagai bagian dasar dalam penentuan efektif tidaknya pelaksanaan sistem pembiayaan yang selalu dibicarakan oleh pihak bank. Kegunaan tersebut ditujukan agar masyarakat mudah menjangkau KPR Subsidi baik dari segi penghasilan dan kemudahan prosedur pengajuan pembiayaan KPR syariah bersubsidi sebagai bagian dari suatu sistem pembiayaan yang benar dan tepat, sehingga para nasabah akan mudah memahaminya (Sukanto \& T. Hani Handoko, 2012).

Berdasarkan indikator kegunaan yang dimasukkan dalam kriteria interprestasi skor, sebesar 85,3\%. Maka dinyatakan bahwa indikator kegunaan KPR syariah bersubsidi pada Bank BTN Syariah Cirebon adalah sangat efektif, yang menandakan bahwa KPR syariah bersubsidi sangat berguna sehingga dapat membantu masyarakat mendapatkan hunian yang layak khususnya masyarakat berpenghasilan rendah.

Dapat dikatakan efektif, karena keefektifan kegunaan KPR syariah bersubsidi dalam indikator yang disebar di masyarakat sebesar $85,3 \%$ bila dibandingkan dengan penelitian sebelumnya menurut Arum (2011) bahwa faktor kegunaan masih kurang efektif dalam KPR Subsidi karena masih belum tersalurkan kepada masyarakat berpenghasilan rendah. Hal ini terjadi akibat dari pola penyaluran dalam program KPR 
syariah bersubsidi dari tahun ke tahun terdapat perubahan yang mendasar sehingga masyarakat sebagai calon nasabah sudah bisa memahami akan prosedur dalam pengajuan pembiayaan.

\section{2) Ketepatan Sasaran}

Bagi masyarakat yang akan mengambil KPR syariah bersubsidi harus tepat sasaran dalam kepemilikan rumah bila tidak tepat sasaran maka apa yang menjadi tujuan utama akan sangat menyimpang. Kemudahan yang disampaikan pihak bank dalam pengambilan rumah bersubsidi harus sampai pada masyarakat sebagai nasabah sehingga masyarakat akan merasa nyaman akan informasi yang di dapat secara tepat mengenai KPR syariah bersubsidi (Sukanto \& T. Hani Handoko, 2012).

Menurut Menteri Pekerjaan Umum dan Perumahan Rakyat No. 242/KTPS/M/2020 kelompok sasaran yang menerima subsidi yakni :

a. Keluarga atau perorangan baik berpenghasilan tetap ataupun tidak tetap

b. Belum pernah menerima rumah subsidi dari pemerintah

c. Memiliki gaji perbulan maksimal Rp 8.000.000

d. Memiliki NPWP

Ketepatan dalam proses pemberian perumahan bersubsidi harus sesuai kriteria dan persyaratan yang jelas. Bukti persyaratan yang jelas yaitu dengan pernyataan yang diketahui oleh atasan serta kelurahan setempat (Desita, 2013). Berdasarkan indikator ketepatan sasaran yang dimasukkan dalam kriteria interprestasi skor, sebesar 84,8\%. Maka dinyatakan bahwa indikator ketepatan sasaran KPR syariah bersubsidi pada Bank BTN Syariah Cirebon adalah sangat efektif, yang menandakan bahwa KPR syariah bersubsidi tepat sasaran karena nasabah yang memiliki KPR syariah bersubsidi merupakan masyarakat berpenghasilan rendah yang tidak melebihi gaji perbulan sebesar Rp 8.000.000.

3) Ruang Lingkup

Ruang lingkup KPR syariah bersubsidi meliputi kemudahan dalam persyaratan pengajuan. Masyarakat berpenghasilan rendah akan turut memperhatikan beberapa prosedur dalam pengambilan rumah bersubsidi, sehingga termudahkan dan yang paling utama adalah nasabah akan berpeluang bila dalam pekerjaannya ada kemapanan sehingga masyarakat yang akan mengambil KPR syariah bersubsidi harus memenuhi persyaratan yang tentunya sudah diverifikasi secara kooperatif yang tertuang dalam peraturan kementerian perumahan rakyat Nomor 10/PRT/M/2019 Pasal 54 ayat (5) (Ravianto J, 2014).

Suatu sistem dikatakan efektif jika mekanisme pembiayaan untuk penyediaan KPR syariah bersubsidi dalam sistem tersebut mudah dijalankan oleh stakeholder yang terkait dalam sistem pembiayaan ini. Stakeholder yang dimaksud yakni Lembaga keuangan (Bank BTN Syariah) dan pengembang (Arum Novia W, Astuti W, \& Galeng Y, 2011). Berdasarkan indikator ruang lingkup yang dimasukkan dalam kriteria interprestasi skor, sebesar 85,0\%. Maka dinyatakan bahwa indikator ruang lingkup KPR syariah bersubsidi pada Bank BTN Syariah Cirebon adalah sangat efektif, yang menandakan bahwa persyaratan dan prosedur dalam pengajuan pembiayaan KPR syariah bersubsidi 
mudah dan tidak memakan waktu yang lama. Ruang lingkup yang dimaksud adalah keringanan dalam pengambilan rumah bersubsidi untuk masyarakat yang membutuhkan dengan persyaratan yang telah memenuhi sesuai dengan program yang ditawarkan oleh bank kepada masyarakat umum sebagai target dari pencapaian program pemerintah dalam rumah layak untuk masyarakat.

4) Efektivitas Biaya

Efektivitas biaya dalam KPR syariah bersubsidi selayaknya akan diperuntukan kepada masyarakat berpenghasilan rendah tetapi ada beberapa hal yang menjadi syaratnya seperti slip gaji penghasilan minimal, KTP, kartu keluarga, tabungan, sehingga persyaratan akan administrasi menjadi efektif terhadap biaya administrasi yang dikenakan nasabah sesuai kemampuan nasabah, biaya tidak tiba-tiba akan muncul di nasabah akan tetapi ada penetapan besaran margin pada Bank BTN Syariah yaitu $5 \%$ sesuai dengan peraturan kementerian perumahan rakyat Nomor 10/PRT/M/2019 Pasal 54 ayat (5) (BTN, 2019).

Berdasarkan indikator efektivitas biaya yang dimasukkan dalam kriteria interprestasi skor, sebesar 85,9\%. Maka dinyatakan bahwa indikator efektivitas biaya KPR syariah bersubsidi pada Bank BTN Syariah Cirebon adalah sangat efektif, yang menandakan bahwa biaya angsuran KPR syariah bersubsidi ringan dan tidak memberatkan nasabah.

\section{5) Ketepatan Waktu}

Dokumen yang lengkap dan tepat waktu akan semakin jelas bila diproses untuk pencairan danaatau KPR syariah bersubsidi secara cepat tanpa ada kendala bila nasabah memperhatikan akan prosedur dan persyaratan secara baik, ketepatan waktu pencairan pembiayaan KPR syariah bersubsidi membutuhkan waktu dalam proses pembiayaannya. KPR syariah bersubsidi perlu waktu yaitu proses waktu yang tidak lama yaitu 1- 2 hari kerja setelah dokumen permintaan pencairan biaya disampaikan. Untuk pembayaran angsuran nasabah diberikan keringanan sesuai dengan aturan yang berlaku pada bank sehingga untuk membayar perlu waktu dalam jangka 15 tahun - 20 tahun (Makmur, 2011).

Berdasarkan indikator ketepatan waktu yang dimasukkan dalam kriteria interprestasi skor, sebesar 81,3\%. Maka dinyatakan bahwa indikator ketepatan waktu KPR syariah bersubsidi pada Bank BTN Syariah Cirebon adalah sangat efektif, yang menandakan bahwa nasabah tergolong tepat waktu dalam membayar angsuran pembiayaan KPR syariah bersubsidi serta pencairan pembiayaan dan jangka waktu pelunasan KPR syariah bersubsidi tergolong cepat.

Penelitian sebelumnya menurut Sulasman (2012) ketepatan waktu KPR syariah bersubsidi masih berdasar pada program yang lama yaitu tepat dalam proses jangka waktu yang telah ditetapkan dan dirumuskan dalam konteks pemenuhan kebutuhan dasar dalam prosedur yang diterapkan, sehingga masyarakat sebagai calon nasabah akan tetap mengikuti aturan dari bank BTN syariah. Penelitian yang dilakukan oleh peneliti bahwa indikator ketepatan waktu KPR syariah bersubsidi adalah sangat efektif, 
hal ini menandakan bahwa ketepatan waktu sangat signifikan bila dibandingkan dengan penelitian sebelumnya.

\section{PENUTUP}

\subsection{Kesimpulan}

Berdasarkan hasil penelitian dan pembahasan yang telah dibahas pada bab sebelumnya, maka dapat disimpulkan bahwa :

1) Pola penyaluran KPR syariah bersubsidi pada PT. Bank BTN Syariah Cirebon terdiri dari prosedur dan mekanisme. Prosedur dalam mengajukan pembiayaan KPR syariah bersubsidi yaitu warga negara Indonesia, menjadi nasabah Bank BTN Syariah, berusia 21 tahun atau sudah menikah, Pada saat pembiayaan lunas atau selesai usia pemohon tidak melebihi 65 tahun atau usia pensiun, belum mendapatkan bantuan rumah subsidi dari Pemerintah, memiliki penghasilan tetap maksimal delapan juta rupiah tidak lebih, mempunyai pekerjaan / usaha minimal 1 tahun, tidak memiliki pembiayaan bermasalah pada bank, melampirkan SPT tahunan atau NPWP. Sedangkan mekanisme dalam KPR syariah bersubsidi yaitu pihak bank memberikan formulir permohonan pembiayaan dan disertai surat pemesanan rumah (SPR) untuk diisi oleh calon nasabah, selanjutnya calon nasabah diminta untuk melampirkan dokumen kelengkapan KPR dan surat pernyataan oleh pihak bank, selanjutnya pihak bank melakukan BI checking dan wawancara terkait pengajuan yang disampaikan serta verifikasi akhir oleh bank.

2) Tingkat efektivitas pembiyaaan KPR Syariah Bersubsidi pada PT. Bank BTN Syariah Cirebon dilihat dari hasil penelitian yang didapatkan pada masing-masing variabel efektivitas dengan indikator kegunaan mendapatkan hasil sangat efektif, ketepatan sasaran mendapatkan hasil sangat efektif, ruang lingkup mendapatkan hasil sangat efektif, efektivitas biaya mendapatkan hasil sangat efektif, dan ketepatan waktu mendapatkan hasil sangat efektif. Dapat disimpulkan bahwa efektivitas pembiayaan KPR Syariah Bersubsidi pada PT. Bank BTN Syariah Cirebon yang dilihat dalam perhitungan efektivitas seluruh indikator mendapatkan hasil sangat efektif.

\subsection{Implikasi dan Rekomendasi}

Secara empiris, implikasi dari hasil penelitian diharapkan dapat menjadi masukan untuk Bank BTN Syariah Cirebon sebagai pertimbangan untuk mendorong lebih banyak produk KPR syariah bersubsidi lainnya dengan tetap memudahkan para nasabah pada proses pengambilan KPR syariah bersubsidi, sehingga kepuasan nasabah dapat dijadikan acuan untuk menciptakan program-program selanjutnya.

Adapun implikasi lainnya dari hasil penelitian secara teori diharapkan mampu memberikan sumbangsih pemikiran dalam pengembangan dan peningkatan ilmu pengetahuan dalam hal ilmu ekonomi perbankan syariah dalam program-program handal. Penelitian ini menunjukkan gambaran dari tingkat efektivitas pembiayaan, proses dan mekanisme KPR syariah bersubsidi pada Bank BTN Syariah, selain itu 
secara praktis bagi masyarakat luas, pelaku bisnis property akan dapat berkembang dan meningkat.

Rekomendasi yang dapat penulis sampaikan dari hasil penelitian ini adalah sebagai berikut :

1) Diharapkan penelitian ini dapat berguna dan bermanfaat bagi masyarakat luas, sehingga masyarakat akan merasakan akan dampak dari program KPR syariah bersubsidi.

2) Pengembangan program KPR syariah bersubsidi tetap perlu dukungan pemerintah pusat dalam pengembangan dan aplikasi lainnya yang dibutuhkan oleh masyarakat masa kini.

3) Dibutuhkan komitmen dan rasa kepedulian yang kuat dari pemerintah untuk tetap mendorong perbankan di Indonesia untuk mengembangkan salah satu program diantaranya adalah KPR syariah bersubsidi.

4) Kenyamanan dalam pengambilan KPR syariah bersubsidi menjadi prioritas utama dalam pelaksanaannya.

5) Sampel pada penelitian selanjutnya sebaiknya lebih banyak lagi dan menyeluruh di semua aspek atau kategori yang lebih luas lagi. Sehingga dapat digeneralisasikan secara menyeluruh atau umum.

6) Penelitian yang berkaitan dengan KPR syariah bersubsidi masih sedikit terutama didaerah. Oleh karena itu sebaiknya penelitian selanjutnya mampu mengeksplore lebih dalam lagi dari berbagai sudut pandang dan keunggulan lainnya.

\section{DAFTAR PUSTAKA}

Abbas, M., Azid , T., \& Azrin Hj, M. H. (2016). Efficiency, Effectiveness and Performance Profile of Islamic and Conventional Banks in Pakistan. Jurnal Humanomics, Vol. 32, No. 1, 4. Retrieved April 6, 2020, from www.emeraldinsight.com

Arum Novia W, Astuti W, \& Galeng Y. (2011). Efektifitas Program Kredit Perumahan

Rakyat (KPR) Bersubsidi Dalam Penyediaan Hunian Bagi Masyarakat Berpenghasilan Rendah Di Perumahan Bumi Rejo Damai Pekalongan. Jurnal Region, 4 (1).

BTN. (2017). KPR Bersubsidi untuk Keluarga Indonesia yang Sejahtera. Retrieved from btn.co.id.

BTN. (2019). Profil BTN Syariah. Retrieved from btn.co.id.

Choiriyah. (2019). Hukum Perbankan dan Perasuransian Indonesia Dalam Perspektif Hukum Islam. Jurnal Sosial Eg Budaya Syar'i, Vol. 6(No. 1).

Desita, D. (2013). Pengendalian Kepemilikan RSH Subsidi di Kelurahan Mateseh Kota Semarang. Jurnal Pembangunan Wilayah dan Kota, 9 (2).

Ferdinand, A. (2014). Metode Penelitian Manajemen. Semarang: Badan Penerbit Universitas Diponegoro. 
Gd Permadi, A. (2018). Implementasi Kebijakan Program Rumah Bersubsidi di Kecamatan Banjar Kabupaten Bulengleng. Jurnal Administrasi Publik Volume 3 No 1,34 .

Juliana, \& Marliana, R. (2016). Preferensi Nasabah Memilih Bank Syariah Dilihat dari Aspek Karakteristik Nasabah. E-QIEN Jurnal Ekonomi dan Bisnis, 4(1), 49.

Juliana, Faathir, M., \& Sulthan, M. A. (2019). Implementasi Etika Bisnis Islam Pelaku Usaha Mikro : Studi Kasus Pada Pelaku Usaha Mikro Syariah Puspa Bank Indonesia Wilayah Jawa Barat Di Bandung Tahun 2017. Jurnal Pendidikan Manajemen Bisnis, 19(1), 38.

Juliana, Marliana, R., Saadillah, R., \& Maryam, S. (2018). Pertumbuhan dan Pemerataan Ekonomi Perspektif Politik Ekonomi Islam. Ekonomi dan Keuangan Syariah, 39(3), 266.

KBBI. (2018). Kamus Besar Bahasa Indonesia. Retrieved from kbbi.web.id.

Makmur. (2011). Efektivitas Kebijakan Kelembagaan Pengawasan . Bandung: Refika Aditama.

Muhammad. (2015). Manajemen Pemasaran Jasa. Bandung: Alfabeta.

Notoatmodjo. (2012). Metodologi Penelitian Kesehatan. Jakarta: Rineka Cipta.

Pusat Pengelolaan Dana Pembiayaan Perumahan. (2020). Keputusan Menteri Pekerjaan Umum dan Perumahan Rakyat Nomor 242. Retrieved from ppdpp.id: www.ppdpp.id

Ravianto J. (2014). Produktivitas dan Pengukuran. Jakarta: Binaman Aksara.

Sholihat, S. (2015). Analisis Efektivitas Pembiayaan Lembaga Keuangan Mikro Syariah Terhadap Perkembangan Usaha Nasabah di Sektor Rill (Usaha Mikro, Kecil dan Menengah). Al-Infaq Ekonomi Islam, 6(1), 19.

Sukanto, R., \& T. Hani Handoko. (2012). Organisasi: Teori Struktur dan Perilaku. Yogyakarta: BPFE.

Sulasman. (2012). Analisis kebutuhan perumahan untuk masayarakat menengah ke bawah di Ogan Permata Indah (OPI) Jaka Baring Palembang. Jurnal Teknik Sipil, Vol. 7, No. 2.

Takalamingan, H. F., Saerang, D. P., \& Kalalo, M. Y. (2018). Analisis Penerapan Sistem dan Prosedur Pemberian Kredit Pemilikan Rumah (KPR) Subsidi Pada Bank Tabungan Negara Cabang Manado. Riset Akuntansi Going Concern, 13(4), 830-831. 